Journal of History Culture and Art Research (ISSN: 2147-0626)

Tarih Kültür ve Sanat Araştırmaları Dergisi

Vol. 9, No. 1, March 2020

\title{
DOI: 10.7596/taksad.v9i1.2472
}

Citation: Vainorenie, I. P., \& Lemish, N. Ye. (2020). Multidisciplinary Aspects of Causality as an Ontological and Epistemological Category. Journal of History Culture and Art Research, 9(1), 305-314. doi:http://dx.doi.org/10.7596/taksad.v9i1.2472

\section{Multidisciplinary Aspects of Causality as an Ontological and Epistemological Category}

\author{
Iryna P. Vainorenie ${ }^{1}$, Nataliya Ye. Lemish ${ }^{2}$
}

\begin{abstract}
The paper deals with describing a variety of interpretations of causality in different branches of modern science focusing on its multidisciplinary aspects. Moreover, historical and genetically reasoned aspects of causality in different areas are highlighted in this work. The authors take for granted that everything observable and calculable is commonly beyond dispute, and a deep understanding of causal reasoning creates an opportunity to govern different processes in various areas of human activity. Hence, interpretation of causality can be related to formal, natural, and social sciences, among which are physics, medicine, logic, philosophy, jurisprudence, psychology, and linguistics. To achieve the purpose of the paper, the authors employed such methods as observation, analysis, deduction, induction, synthesis, and description. The study proves that application of ideas obtained from physics (the hypothetical theory of a multiverse existence), logic (the implicative connection between actions), philosophy (generation of one phenomenon by another in both objective and subjective reality), psycholinguistics (the notion of mental causation), and linguistics (variety of linguistic means to express causality in different languages) shapes views of people on the interpretation of the phenomenon of causality and contributes to further comprehensive study of the causality using different approaches, linguistic inclusive. The paper also provides evidence for the causal reasoning being one of the most important mechanisms of categorization of the real world, thus making causality multidimensional. In conclusion, it is worth mentioning that modern global processes in all areas of human life demand a higher level of cross-cultural communication. The abovementioned signifies that one should be cautious in choosing language means to reflect the nuances of causal fragment of his/her worldview in order to be properly understood by speakers not only of other languages/cultures, but also by their own, for different speakers can perceive and interpret reality differently.
\end{abstract}

Keywords: Causality, Causal reasoning, Categorization, Mental causation, Worldview, Multidimensional.

\footnotetext{
${ }^{1}$ Ph.D. student, senior lecturer at the Department of Applied Language Studies, Comparative Linguistics and Translation. National Pedagogical Dragomanov University, Kyiv, Ukraine. ORCID no: 0000-0003-0198-1448. Email: barong@i.ua

2 National Pedagogical Dragomanov University, Kyiv, Ukraine. ORCID no: 0000-0001-5321-4705. E-mail: lemish1972@gmail.com
} 


\section{Introduction}

Global processes in all areas of human life demand a higher level of cross-cultural communication (Batsevych, 2009; Chodzkiene, 2014; Selivanova, 2011, and others). Causality, being one of the most important concepts of human civilization, has a long history since a simple perception of cause / reason, its inseparable connection with result and consequence to a complex cognitive system / construct known as a causal complex. Causal reasoning is one of the most important mechanisms of the reality categorization (Lemish, 2015a, p. 14) Moreover, a deep understanding of causal reasoning creates an opportunity to govern different processes in Politics, Economics, Jurisprudence, and other areas of human activity.

The phenomenon of causality has been in the center of discussion for more than 2000 years. In the IVth century B.C., Aristotle defined four causes: material, formal, efficient (moving), and final (Falcon, 2019; The Metaphysics of Aristotle, 1801, B. V, p. 110-111), which still serve as a basis for many theories in various disciplines trying to deepen, expand, contradict, or change causality / causation principles.

With the interpretation of language as a means of human thought formalization and representation (Amatov, 2010; Neeleman et al., 2012, and others), mapping and expressing the universal and specific phenomena of reality by native speakers in different languages have become one of the major challenges in modern Linguistics (Lemish, 2013). Besides, researches in the above field are considered relevant to such problems as "language - thinking", "language - consciousness", "language" - "cognition" (Kubryakova, 2004; Kurhut, 2002; Zahnitko, 2011). In modern Linguistics causality is interpreted as a causal complex (Amatov, 2010; KHaag, 2004; Komarov, 1970; Lemish, 2014a, 2014b; Mikhailova, 2010; Tazhybaeva, 2001, and others).

While studying the phenomenon of cause-and-reason relations, an agent structures the obtained data and represents them in the language. Thus, mental and logical actions are interrelated and reflected in the language. According to Shcherba, mind and language make a single unity, hence, language observation means mind observation since "the last one can't be observed beyond language forms" (1974, p. 339).

We consider that causality can be interpreted as an ontological and epistemological category. Ontologically it represents a causal situation meaning a fragment of natural / virtual reality in which objects at a certain time in a certain place are connected with a causal relationship. In addition, such a situation is restricted and interpreted by a speaker from a communicative and pragmatic standpoint (Lemish, 2015b, p. 4). Epistemologically this category can be represented by a causal complex that covers all the possible constituents facilitating to cognize the world. The more a person is aware of causal manifestations in different areas of life, the easier he / she can come to just conclusions and, hence, the better improve his / her personal and social position.

Thus, the main purpose of this paper is to describe the interpretation of causality in different branches of modern science focusing on its multidisciplinary aspects.

The major methods employed in this study include observation, analysis, deduction, induction, synthesis, and description.

\section{Interpretation of causality in natural and formal sciences}

Taking into account that everything observable and calculable is commonly beyond dispute, interpretation of causality can be related to all branches of scientific activity, among which are Philosophy, Logic, Physics, Medicine, Psychology, Linguistics, Jurisprudence, and others. 
First of all, we would like to draw attention here to the idea that parallel worlds may exist. A possible explanation of it can be found in Einstein's theory of relativity (both special and general) (Einshtein, 1922; Trautman, 2006), according to which gravity is defined as the curvature of spacetime continuum. Consequently, the concept of simultaneity is relative: two events, simultaneous for one observer, may not be simultaneous for another observer, if the observers are in relative motion. The given fact implies that there may be more than three dimensions. Then string / superstring theory (Polchinski, 2005; Schwartz, 2007) describes all the fundamental forces and forms of matter, that require the existence of extraspatial dimensions. The Heisenberg's Uncertainty principle (Furuta, 2012; Hedenmalm, 2012) determines the correlation between the position and momentum of the particles, stating that the more precisely the position of some particle is determined, the less precisely its momentum can be. All of the above-mentioned fundamental discoveries in Physics laid the foundations for the hypothetical parallel universe (or multiverse) theory (Greene, 2011). Therefore, it could be argued that languages can form a kind of "multiverse" existing in separate dimensions but permanently interacting with one another (Lemish, 2015a, p. 105-106).

Dynamic modeling directly linked to causal inference is widely applied in Medicine, particularly in Epidemiology, where it helps to detect symptoms of diseases, fixing diagnoses and prescribing an appropriate treatment. A causality model, that describes causes in terms of sufficient reasons and their constituents, illuminates a multi-causality principle when the strength of its constituents depend upon the prevalence of complementary reasons in their interaction (Galea et. al., 2009). Most epidemiologists, however, agree with Hume and Popper that "causal inferences cannot attain the certainty of logical deductions" (Lewis, 1973), in other words, come down to causal hypotheses.

One of the most important ways of understanding causality is to interpret it from a logical perspective. Traditionally, Logic considers a language to be a means of expressing basic forms of reasoning including concepts, judgments, and inferences. It happens so because in Logic execution of a thought expression through correct lingual codes plays a crucial role, and all logical results relating to inferences are formulated in case of being applied to the correct sentences only (Gzhegorchik, 1979, p. 13).

It would be of special interest to study the law of implicative syllogisms, since it is applied in the sentences with cause-and-effect relations. In our opinion, they build the basis for all causal microstructures. The notion of implication (from Latin implicatio - "entwining", implico - "being entwined") is generally defined as a logic operation that is to join two statements by means of a logical connection with the aim to form a compound statement. The implication itself captures neither conditional, nor causal, nor any other semantic connection. Its meaning is encompassed by the truth of a compound statement dependence on the truth of its components.

In Logic, the content of the implicative connection is most adequately rendered by a compound sentence with the conjunction if (якщо), which is called a conditional sentence or ifsentence. However, a number of scholars have recognized that the implicative connection does not fully comply with the conditional relation, and that language constructions do not correspond to the logic operations, but only partially correlate with them (KHrakovskii, 1998, p. 29). The logical conditional connection is formalized through the process of constructing counterfactual implications. To express the causal connection, the causal implication is used. It can be represented by the formula $\mathrm{A} \perp \mathrm{B}$, where the sign $\perp$ indicates the connection between the components $A$ and $B$ (Logicheskii slovar, 1975 , p. 241). It can be interpreted as a general implication formula $A \rightarrow B$ : if $A$, then $B$. The formula $A \perp B$ means generally $B$ being caused by $A$, that is, the connection reflects both substantive and causal (logic) links. The logic and structural invariant of the cause can be extracted from various types 
of sentences with relations of causal implication. The causal implication is characterized by three ontological properties: obligatoriness, geneticity, and asymmetry. These characteristics form the integral and differential basis for both a general correlation of causal implication and its components. Thus, the logic defines causality as a notional category expressing substantive and logical causal relations that are represented by various language codes at different levels.

It is of particular interest to investigate a causal approach in Neurology proposed by Seth (2006). He suggests that neural systems can be analyzed in terms of causal networks (neurons engage in causal interactions with one another and with a surrounding body and environment itself). It should be noted that the mentioned experiment is carried out based on modeled neural systems with a combination of the analysis of time series (according to the Granger's causality based on the forecasting process). If we have the prediction that $\mathrm{X} 1 \rightarrow \mathrm{X} 2$, where a signal $\mathrm{X} 1$ causes a signal $\mathrm{X} 2$, then past values of $\mathrm{X} 1$ should contain information that helps predict $\mathrm{X} 2$. It is important to mention that the behavior of neurons may vary, but the scholar claims that analysis of causal interactions accompanied by selection of specific features indicates the regular shift, by which he means differential dynamic repertoire of neural interactions adjusting causal center for learning / acquisition. Neurological interpretation of the results suggests that there is a reason for focusing individual attention on the certain dominant or dominants of a causal complex. It appears to be a natural result of previous experiences of a person or particular contexts.

Since the object of our study is the category of causality represented by a mental (logical) construct, we need to specify the meaning of the mental causation. The term "mental causation" applies to a kind of causal category involving mental states of volitions (Lemish, 2011; Vezhbitskaia, 1997; Wierzbicka, 1996) such as desires, goodwill, consciousness, intentionality (philosophy of mind), and model of the Type of Information Metabolism (Psychology) which is characterized by various means of expression in different languages.

Representatives of each type of information metabolism have their own peculiar vocabulary, which means that lexical criteria may be applied to identify the type. People struggle to understand one another because of different interpretation of reality by different individuals.

The only way for the thoughts to be stored and accumulated is language means. The language does affect thinking (either clarifies or misleads), however, there is no correlation between mental representation and its linguistic structure. What makes it worse is a real-life communication and intercultural communication in particular. Thus, the psychological approach to the study of language and mental causation has proven useful (language + thinking + consciousness $=$ psycholinguistics).

Interconnected processes of logic phenomena, mental constructs (concepts, images, and frames), built under the influence of linguistic and extralinguistic factors, are perceived differently by representatives of different nations. Nikitin states that "we can deal with one and the same object of a conceptual level of abstracting and generalizing units in our consciousness but consider these units in different dimensions with different aims: in one case we are interested in what they reflect, in another - how they are expressed" (1996, p. 89).

The problem of mental causation is a conceptual issue in the philosophy of consciousness. The essence of the mentioned issue is how to explain a general fact, that intentional thoughts or intentional mental states cause intentional actions (Problem of Mental Causation).

At first sight, the basic problem of mental causation is an intuitive one and we need to cognize it. Mental actions cause physical actions and vice versa. However, it is clear that not all desires can cause physical actions. Hence, the problem divides into several distinct sub-problems, 
including causal exclusion, anomalism, and externalism (the so-called external action or sensory perception).

The cause-and-effect relationships between facts and human actions constitute a fundamental part of general knowledge about the world (a philosophical aspect). Therefore, causal relations are clear due to semantic specifics of their components even in case of unmarked means in the whole text (for example, in asyndetic sentences).

The important role in mental causation studying is played by cognitive psychology and cognitive linguistics. The reason is that the brain receives information about the outside world with the help of five senses (physiology), stores and processes data (psychology), figures out and interprets information (logic) and formulates it as sentences / utterances or thoughts (linguistics).

The semantics of mental causation interacts with the semantics of control since argumentation may be both subjective and objective (Podlesskaya, 1993, p. 173). If a conclusion is caused by natural conditions, it cannot be controlled by a speaker, and is only observed by him/her, hence, a control is absent. However, in situations involving the speaker's opinion, behavior, attitude, or social status, the agent tries to control or to eliminate control by engaging the listener in observing and estimating the situation.

\section{Interpretation of causality in social sciences}

Interpretation of causality as a philosophical concept encompasses a range of cause-andeffect relationships. A neutral definition is almost impossible since every aspect of causality adds to a holistic understanding of the concept itself. In its broadest sense, the causality is a connection or linkage between events, subjects/objects, and states. Causal relationships indicate that the cause produces consequence or, at least, its possibility.

Philosophy defines the cause as a phenomenon that causes one thing under certain conditions, gives rise to, changes or generates something else; the latter is called the effect or the consequence. The consequence depends on a definite diversity of conditions. Every reason is a cause in some respect, and every cause may become a consequence. Thus, under different circumstances, the consequence may transform into a cause / reason for the other effect / consequence (Filosofskii entsyklopedicheskii slovar, 1983, p. 531).

Historical and genetic links of the category of causality demonstrate its connection with the categories of purpose, place, time, conditions and concession. Nevertheless, the category of causality is a higher order category. The mentioned categories subordinate to the category of causality, and being its components, form a single causal complex.

Thus, a causal complex consists of several binomials (the precise number varies according to the research principles) and presents a range of relations such as cause - effect, reason - conclusion, condition - result, concession - consequence, purpose - means. The distinguishing and isolating of causality from other phenomena can be achieved only through abstraction.

Classification of cause-and-effect relations in modern science relies on various criteria. According to the nature of their relations, they are divided into material and ideal, informational and energetic, physical, chemical, biological and social; according to the type of connection, there are dynamic and static cause-and-effect relations; according to the amount and coherence of impact they may be divided into simple, compound, multifactorial, systemic, and non-systemic cause-andeffect relations (KHaag, 2004, p. 11). Moreover, there are external and internal; main and secondary; objective and subjective; general, special, single, etc. causes (Filosofskii entsyklopedicheskii slovar, 1983, p. 531). 
A phenomenon (a process, an action) is defined as a cause of another phenomenon (a process, an action) if: 1 ) it precedes its effects temporally; 2 ) the first is a necessary condition for the occurrence, change or development of the other one. Namely, in case the first phenomenon / process / action generates the second one. Cause and effect being an objective phenomenon, their connections are designated as causality or cause-and-effect relation (Filosofskii slovar, 1981).

The essential properties of causal relation that ontologically distinguish it from the other types of relations are as follows below:

1) obligatoriness (understood as an intrinsic and inseparable connection between cause and effect, when the effect inevitably results from the cause but not follows it mechanically, according to Komarov) means that cause and effect are connected with the relationship of internal necessity (a phenomenon cause includes a phenomenon consequence);

2) geneticity (the structure of the effect is reflected in the structure of the cause) means the transfer of the structure from cause to effect: the structure of the effect reproduces or represents the structure of the cause;

3) asymmetry means that cause-and-effect relationships are strictly directional, and cause and effect relation refers to a connection between two phenomena in which one defines the other (Komarov, 1970, p. 17-19). Cause and effect are contiguous in space and time, and the causality forms asymmetric relationships.

Unlike other types of relations, the causality is able to generate or determine one phenomenon by another, which underlies the genetic connection between its components and represents its main ontological property. Causal connection (generation) is one of the main forms of interrelation and dependence of the objects of reality, and, in our understanding, underlies not only one microstructure of a causal complex such as cause - effect, but also of reason - conclusion, condition - result, concession - consequence, and purpose - means. Cause and effect as philosophical categories are naturally inherent in both thinking and language.

The categorial apparatus of Jurisprudence also includes definitions / interpretations of the causal complex constituents (cause, reason, condition, concession, purpose, effect, conclusion, result, consequence, and means) which implement the ontological and epistemological category of causality.

In criminal law, for example, causal relationships are defined as an objective connection between the action / activity or inactivity (cause) and socially dangerous consequences (effect), in case an activity or inactivity causes (produces) socially dangerous consequences (Kryminalne pravo Ukrainy, 2010, pp.129-130). The main features of causality include its necessity and randomness. Establishing a necessary causal connection is required to establish the subject of a crime. The necessary causal connection takes place in case:

a) a cause is prior to an effect in time;

b) a cause always produces an effect;

c) a cause is a dominant condition that may lead to a socially dangerous consequence;

d) a cause inevitably results in a socially dangerous consequence.

The causal connection between causes and effects has to be artificially isolated from the rest of cause-and-effect relations so that we can see this connection in its "pure form". Since the effect is always a consequence of something (Ozhegov, 1990, p. 745), in law, it is regarded as a necessary component of the causal connection. 
The purpose as a constituent of the causal complex is one of the most widely used notions in the Criminal Code. Hence, a purpose is a desired result that a person envisions, plans and commits to achieve, determining the direction of an activity (Kryminalne pravo Ukrainy, 2010, p. 173).

As for the reason, it is considered to be a source, a basis for structuring something, that is it is its core sense (Ozhegov, 1990, p. 372). For instance, Chapter IX of the Preliminary part of the Criminal Code of Ukraine contains provisions concerning legal reasons, as well as order and cases of the criminal liability release.

As for the causal dominant conclusion, the judges, considering and examining the premises and grounds for discharging from criminal liability, infer the necessity for this measure, that is, they draw the conclusion, what in fact is consistent with its definition (Ozhegov, 1990, p. 91).

The result is the final result of a particular action or situation (Ozhegov, 1990, p. 551). Based on the made conclusion a judge proclaims a decision concerning grounds for discharging a person from criminal liability.

In legal meaning, the causal dominant concession correlates with the similar notion of hypothesis which is interpreted as "an element of the legal rules that prescribes the conditions under which the behavior patterns are to be applied (disposition)" (Zahalna teoriia derzhavy, 2009, p. 234). Therefore, the legal conceptual framework interprets general legal notions in terms of causal dominants notions proposed in our research, specifying their meanings for particular situations and legal cases.

Causality in Linguistics has been studied from different points of view with a focus on various language objects, namely: causal prepositions and conjunctions (KHaag, 2004; Lemish, 2015a), simple (lashchenko, 2007), and complex sentences (Lemish, 2015a; Zelenska, 1993), using a functional (Amatov, 2010; Sanders et al., 2009), or a corpus approach (Vainorenie, 2017, 2018). Causal semantics was thoroughly investigated by Katsnelson (1972), Komarov (1970), and others. In modern Linguistics causality is interpreted as the causal complex (Amatov, 2010; KHaag, 2004; Lemish, 2015a; Tazhybaeva, 2001, and others). Studying the causal complex as a mental and logical construct that represents the ontological and epistemological category of causality in an individual consciousness (as noted by prof. Lemish, 2015a, 2015b) makes it possible to identify 10 causal dominants (cause, reason, condition, concession, purpose, effect, conclusion, result, consequence, means). Linguistic means used to express the abovementioned dominants can vary a lot not only among speakers of different languages (because of their divergent lexical, morphological, and syntactic systems), but also among speakers of one and the same language depending upon their personal background and professional area. Hence, one should be cautious in choosing language means to reflect the nuances of causal fragment of national worldview in order to be properly understood by speakers, especially if their native language / culture is different.

\section{Discussion and conclusions}

Thus, having studied the multidisciplinarity of causality as of an ontological and epistemological category we came to the following conclusions:

- the events are generated both by objective and subjective reality;

- the existence of one action is always triggered by another (or even several other actions combined);

- a causal complex representing the category of causality in minds of people speaking different languages exists in a kind of multiverse (following ideas from Physics); 
- a structure of the causal complex determines the structure of reasoning and ways of understanding the world;

- $\quad$ one causal notion is bound up with at least two more terms within a causal complex;

- the language is inseparable from the speaker and consists of physical and psychological components;

- perception and language expression of causality mostly depends on mental development, insight and life experience of individuals;

- $\quad$ certain semantic relations may appear either more general (causal) or more specific (degree of argumentation, ability to control, and ability to estimate);

- $\quad$ mental causation is a kind of causal category that is directly related to the problems of volition, and has specific means of expression in different languages.

- the notion of mental causation is inherent in language, reasoning, and consciousness;

- $\quad$ the type of information metabolism defines the speaker's ability to participate in communication, as well as his / her social position;

- $\quad$ with the aim to detect a specific type of causality, one may need the knowledge of Philosophy, Logic, Psychology, and Linguistics;

- $\quad$ to prevent misunderstandings, thoughts are to be formulated by proper linguistic means.

The application of ideas obtained from Physics (as for possible multiverse existence), Logic (the implicative connection between actions), Philosophy (one phenomenon generates another in both objective and subjective reality), Psycholinguistics (the notion of mental causation), and Linguistics (variety of linguistic means to express causality in different languages) shapes our views on the interpretation of the phenomenon of causality and contributes to further comprehensive study of the causality using different approaches, linguistic inclusive.

\section{References}

Amatov, A. M. (2010). Prichinnost $v$ iazykoznanii kak otrazhenie filosofskoi kategorii kauzalnosti. Nauchnye vedomosti. Seriia Gumanitarnye nauki, 6, 12(83), 5-12. (In Russian).

Batsevych, F. S. (2009). Osnovy komunikatyvnoi linhvistyky. (2-he vyd., dop.). Kyiv: Vyd. tsentr "Akademiia". (In Ukrainian).

Chodzkiene, L. (2014). What Every Student Should Know About Intercultural Communication. Vilnius.

Einshtein, A. (1922). O spetsialnoi i obshchei teorii otnositelnosti. S. la. Livshyts (Red.). Moskva: Gosudarstvennoie izdatelstvo. (In Russian).

Falcon, A. (2019). Aristotle on Causality. The Stanford Encyclopedia of Philosophy (Spring 2019 Edition). E.N. Zalta (Ed.). Available at: https://plato.stanford.edu/archives/spr2019/entries/aristotlecausality/.

Filosofskii entsyklopedicheskii slovar. (1983). L. F. Ilichev, P. N. Fedoseev, S.M. Kovalev, \& V. G. Panov (Red.). Moskva: Sov. Entsyklopediia. (In Russian).

Filosofskii slovar. (1981). I. T. Frolov (Red.). (4-e izd.). Moskva: Politizdat. (In Russian).

Furuta, A. (2012). One Thing is Certain: Heisenberg's Uncertainty Principle is Not Dead. Scientific American. Available at: http://www.scientificamerican.com/article/heisenbergs-uncertainty-principle-is- 
not-dead/.

Galea, S., Riddle, M., \& Kaplan, G. A. (2009). Causal thinking and complex system approaches in epidemiology. International Journal of Epidemiology, 39, 97-106.

Greene, B. (2011). The hidden reality, a Physicist Explains Why Parallel Universes May Exist. New York: Random House.

Gzhegorchik, A. (1979). Populiarnaia logika (Obshchedostupnyi ocherk logiki predlozhenii). 3-e izd., stereotip. Moskva: Nauka. (In Russian).

Hedenmalm, H. (2012). Heisenberg's uncertainty principle in the sense of Beurling. Analytical Mathematics, 118(2), 691-702.

lashchenko, T. A. (2007). Kauzatsiia $v$ rosiiskii movi: ontolohiia ta kontseptualizatsiia. (Avtoreferat disertatsiyi na zdobuttya naukovoho stupenya doktora filolohichnyh nauk). Kyiv: Kyivskyi Natsionalnyi universytet imeni T. H. Shevchenka, Instytut filolohiyi. (In Ukrainian).

Katsnelson, S. D. (1972). Tipologiia iazyka i rechevoe myshlenie. Leningrad: Nauka. (In Russian).

KHaag, E-O. (2004). Funktsionalnaia tipologiia $i$ sredstva vyrazheniia prichinno-sledstvennykh otnoshenii v sovremennom russkom iazyke. Tartu. (In Russian).

KHrakovskii, V.S. (1998). Teoreticheskii analiz uslovnykh konstruktsii (semantika, ischislenie, tipologiia). Tipologiia uslovnykh konstruktsii. Sanktpeterburg, 1, 7-96. (In Russian).

Komarov, A. P. (1970). O lingvisticheskom statuse kauzalnoi sviazi. Alma-Ata. (In Russian).

Kryminalne pravo Ukrainy: Zahalna chastyna: pidruchnyk (2010). ред. V. V. Stashys, \& V. la. Tatsii (Eds.). 4-te vyd., pererobl. i dopovn. KHarkiv: Pravo. (In Ukrainian).

Kubriakova, E.S. (2004). Yazyk i znanie: Na puty polucheniia znanii o iazyke: Chasty rechy $s$ kognitivnoi tochky zreniia. Rol iazyka v poznanii mira. Moskva: Editorial URSS. (In Russian).

Kurhut, L. P. (2002). Funktsionalno-hramatychna katehoriia prychyny ta naslidku. Movni $i$ kontseptualni kartyny svitu. Kyiv: Kyivskyi Natsionalnyi universytet imeni T. H. Shevchenka, Instytut filolohii. 7. 285-290. (In Ukrainian).

Lemish, N. (2014a). A Structural and Semantic Typology of the Causal Complex in English. Austrian Journal of Humanities and Social Sciences. Section 11. Philology and Linguistics. Vienna: "EastWest" Association for Advanced Studies and Higher Education, GmbH, 7-8, 221-225.

Lemish, N. (2014b). Causal Complex Dominant Semantics in English and Dutch: a Comparative Study. Australian Journal of Scientific Research, 2(6), 656-663.

Lemish, N. Ye. (2011). Mentalna kauzatsiia ta kauzalni vidnoshennia. Mova i kultura. Kyiv: Vydavnychyi Dim Dmytra Buraho. Vol. X (143). 15. 153-158. (In Ukrainian).

Lemish, N. Ye. (2013). Kategoriya kauzalnosti ta specyfichnist yiyi linhvistychnoyi realizatsiyi. Studia Linguistica 7. Kyiv: Vydavnychyi dim Dmytra Buraho. (In Ukrainian).

Lemish, N. Ye. (2015a). Verteralni typy kauzalnosti u sporidnenykh movakh. Zhytomyr: vydavnychyw tsentr Zhytomyrskoho derzhavnoho universytetu imeni Ivana Franka. (In Ukrainian).

Lemish, N. Ye. (2015b). Komunikatyvno-prahmatychni ta strukturno-semantychni haracterystyky kauzalnoho kompleksu $v$ suchasnyh hermanskyh, romanskykh ta slovyanskyh movah: zistavnotypolohichnyi aspect. (Avtoreferat disertatsii na zdobuttia naukovoho stupenia doktora filolohichnyh nauk). Kyiv: Kyivskyi natsionalnyi lingvistychnyi universytet. (In Ukrainian).

Lewis, D. (1973). Causation. The Journal of Philosophy, 70(17), 556-567.

Logicheskii slovar-spravochnik. (1975). N. I. Kondakov (Ed.). Moskva: Nauka. (In Russian). 
Mikhailova, Z. F. (2010). Invariantnyi integriruiushchii priznak funktsionalno-semanticheskikh kategorii kauzalnogo kompleksa (na materiale nemetskogo iazyka). V mire nauchnykh otkrytii. 4-12. 132-134. (In Russian).

Neeleman, A., Koot, H. van de. (2012). The Linguistic Expression of Causation. The Theta System: Argument Structure at the Interface. Oxford: Oxford University Press. 20-51.

Nikitin, M. V. (1996). Kurs lingvisticheskoj semantiki. Sankt-Peterburg, Leningrad: Nauka. (In Russian).

Ozhegov, S. I. (1990). Slovar russkogo yazyka. N. Yu. Shvedova (Red.). (22-e izd., ster.). Moskva: Russkiy yazyk. (In Russian).

Podlesskaya, V. I. (1993). Causatives and causality: towards a semantic typology of causal relations. In Comries, B. \& Polinsky, M. (eds.), Causatives and Transitivity, (pp.165-176). Amsterdam: John Benjamins Publishing Company.

Polchinski, J. (2005). String Theory. Vol. I. An Introduction to the Bosonic String. Cambridge: Cambridge University Press.

Problem of Mental Causation. Available at: http://en.wikipedia.org/wiki/Problem of mental causation.

Sanders, T. Sanders, J., \& Sweetser, E. (2009). Causality, cognition and communication: A mental space analysis of subjectivity in causal connectives. In Sanders, T. \& Sweetser, E. (eds.), (pp.19-59). Causal Categories in Discourse and Cognition. The Hague: Mouton de Gruyter.

Schwartz, J. H. (2007). String Theory: Progress and Problems. Progress of Theoretical Physics Supplement.

Selivanova, O. O. (2011). Osnovy teorii movnoi komunikatsii: pidruchnyk. Cherkasy: Vyd-vo Chabanenko Yu. A. (In Ukrainian).

Seth, A. K. (2006). Causal networks in neural systems: From water mazes to consciousness. Proc. Brain Inspired Cognitive Systems. Aleksander, I. (Ed.). (BICS2006).

Shcherba, L. V. (1974). Yazykovaya sistema i rechevaya deyatel'nost'. Leningrad: Nauka. (In Russian).

Svetlov, V. A. (1995). Prakticheskaia logika. Sanktpeterburg. (In Russian).

Tazhybaeva, S. Zh. (2001). Kauzalnye konstruktsii i ikh mesto v sisteme iazyka na primere kazakhskikh kauzalnikh konstruktsii. Rossiiskii lingvisticheskii ezhegodnik (RLE). 3. 143-150. (In Russian).

The Metaphysics of Aristotle. (1801). (transl. from the Greek by Th. Taylor). London.

Trautman, A. (2006). Einstein-Cartan theory. Encyclopedia of Mathematical Physics. Elsevier. Vol. 2. 189-195.

Vainorene, I. (2017). Mizhdystsyplinarnist kategoriyi "efect". International research and practice conference "Modern philology: relevant issues and prospects of research»: Conference proceedings, October 20-21, 2017. Lublin: Izdevnieciba «Baltija Publishing». 152-155. (In Ukrainian).

Vainorene, I. (2018). Collocations with "Effect" in English and in Ukrainian: common and specific. Language in Different Contexts. Vilnius: Lietuvos edukologijos universiteto leidykla, 94-101.

Vezhbitskaia, A. (1997). Iazyk. Kultura. Poznanie / per. s angl. M. A. Krongauz (Ed.). Moskva: Russkiye slovari. (In Russian).

Wierzbicka, A. (1996). Semantic primes and universals. Oxford: Oxford University Press.

Zahalna teoriia derzhavy i prava: pidruchnyk. (2009). M.V. Tsvik, \& O. V. Petryshyn (Red.). Kharkiv: Pravo. (In Ukrainian).

Zahnitko, A. P. (2011). Filosofski osnovy suchasnoho linhvistychnoho analityzmu. Available at: http://litmisto.org.ua/?p=679. (In Ukrainian).

Zelenska, O. P. (1993). Kauzalnist u filosofiyi, lohitsi ta movi. Movoznavstvo. 4. 63-67. (In Ukrainian). 